\title{
ENFORCEMENT OF LAW OF COPYRIGHT INFRINGEMENT AND FORGERY WITH THE RISE OF THE DIGITAL MUSIC INDUSTRY
}

\author{
Nevey Varida Ariani \\ Research and Development Board for Law and Human \\ Rights of the Republic of Indonesia \\ Corresponding email: nevey.ariani@yahoo.com \\ Paper received on: 31-03-2021; Revised on: 23-04-2021; Approved to be published on: 06-05-2021 \\ DOI: http://dx.doi.org/10.30641/dejure.2021.V21.223-236
}

\begin{abstract}
The current pandemic situation encourages musicians to be productive in creating digital works such as songs and music so that their creative works can produce moral and economic values. However, infringement and forgery of digital music works are rampant. The issue of royalties is still a problem in the digital music industry in Indonesia, including new challenges to the role of aggregators and Collective Management Organization. The problem of this research is how the enforcement of the law of copyright infringement and forgery is with the emergence of the digital industry. This research used a qualitative method with a normative juridical approach. The results of the research showed that the increasing and complicated law enforcement related to digital music copyright is influenced by regulations such as complaint offense that hindered the law enforcement. The process of coordination and supervision between the Civil Servant Investigator (PPNS) of the Directorate General of Intellectual Property and other law enforcement officers needs to be improved. Law enforcement includes payment of compensation, termination of certain activities that cause harm to creators and owners of related rights, obligation to withdraw from circulation, revocation of business licenses, termination of business activities, and the last resort of ultimum remedium in the form of criminal sanctions. Dissemination of information and knowledge regarding IPR law and its derivative regulations including Government Regulation No. 50 Year 2021 carried out by the government is part of the legal protection of the society to increase public legal awareness in the digital era.
\end{abstract}

Keywords: copyright; industry; music; digital

\section{INTRODUCTION}

Law Number 28 Year 2014 concerning Copyright has provided a basis for protection and legal certainty for the economic rights of Creators, Copyright Holders, and Owners of Related Rights to songs and/or music in enhancing national creativity, particularly in the field of songs and/or music. Works in the form of songs and/or music have economic rights for commercial use in the form of royalties, namely compensation for the use of economic rights of a work or product of Related Rights received by the Creator and the owner of the Related Rights ${ }^{1}$.

Protection of creators' economic rights, especially since the emergence of the Information Technology (IT) revolution which was marked by the widespread use of the Internet as a means of communication. In the digital era, exploitation of copyrighted works is increasingly intensive, complex, and multifaceted, so that it tends to

Peraturan Pemerintah Republik Indonesia Nomor 50 Tahun 2021 Tentang Pengelolaan Royalti Hak Cipta Lagu Dan/Atau Musik ignore respect for the economic rights of creators ${ }^{2}$.

Currently, the public can easily access and gain information in the form of digital information products, including music works. However, this leads to copyright infringement which is often ignored. This happens because it is so easy for people to copy and modify these digital products 3 .

Basically, the holders and owners of Copyright in the field of digital music has the right to freely control their IPR by using an agreement to set conditions for anyone who uses their intellectual creations. Theoretically, the IPR holder will have the exclusive right to have a legalized monopoly on the creation or invention for a certain period of time ${ }^{4}$.

\footnotetext{
2 Imas Rosidawati Wiradirja, "Pelanggaran Hak Moral Atas Karya Cipta Dalam Penerbitan Elektronik," Jurnal Ilmu Hukum Litigasi 14, no. 1 (2013): 1662-1697.

3 Adam Behr, Keith Negus, and John Street, "The Sampling Continuum: Musical Aesthetics and Ethics in the Age of Digital Production," Journal for Cultural Research 21, no. 3 (2017): 223-240, http://doi.org/10.10 8o/14797585.2017.1338277.

4 Rahmi Jened, "Konflik Yurisdiksi Dan Penegakan
} 
This exclusive right has an economic right dimension, which usually brings economic compensation, such as royalties, and a moral right dimension, which perpetuates the integrity of the intellectual creation concerned, which is prone to infringement and forgery of digital copyrighted works ${ }^{5}$.

The current issues related to royalties of digital media are important to be regulated, including in Government Regulation No. 50 Year 2021 concerning Management of Song and/or Music Copyright Royalties ${ }^{6}$. Prevention efforts against copyright infringement, for example acts against the law (tort), unfair competition and contract law. Regarding organized online crime, it will be difficult to find a security network and it is a very significant threat and is growing widely, including in the digital music platform industry ${ }^{7}$.

Digital music platforms like YouTube and Spotify actually have their own rules about paying royalties for creators and owners of related rights. Spotify has two types of royalties. First, recording royalties come from every song played on Spotify and are paid to the artist through the record label or distributor. Second, publisher royalties where royalties are given to writers or composition owners through a collective management agency and agencies located in the user's area. Although digital platforms already have a mechanism for paying royalties, the absence of a legal basis for regulating digital platforms makes the digital music royalty distribution system encounter several obstacles ${ }^{8}$.

There are several problems that still have to be faced by creators in calculating royalties ${ }^{9}$. First, there is no music database in Indonesia that contains at least data on the creators and owners of related rights of each song in circulation. This

Hukum Kekayaan Intelektual Dalam Rangka Pasar Tunggal," Mimbar Hukum - Fakultas Hukum Universitas Gadjah Mada 28, no. 2 (2016): 201.

5 Wiradirja, "Pelanggaran Hak Moral Atas Karya Cipta Dalam Penerbitan ElektroniK.” Jurnal Ilmu Hukum Litigasi Volume 14 Nomorı Tahun 2013 hal 1662-1667

6 Ibid.

7 Rita Kusmayanti, "Perbandingan Hukum Hak Cipta Fotografi Tanpa Izin Pencipta Di Indonesia Dan Amerika" 2, no. 2 (2018): 274-284.

8 Ginting, AR, "Peran Lembaga Manajemen Kolektif Nasional dalam Perkembangan Aplikasi Musik Streaming", Jurnal Ilmiah Kebijakan Hukum Vol 13, No.3, November 2019, p.379-398

9 Ibid. database is important considering that digital platforms often find it difficult to distribute royalties because they are unable to identify the owner of copyright of a work. Second, there is no legal umbrella that regulates the minimum royalty rate, which results in the low bargaining position of Indonesian musicians. Third, Indonesia does not yet have a legal basis that regulates the onestop royalty payment mechanism, so this is often one of the objects in the current violations and forgeries.

The implementation of the Copyright Law in the field of digital music states that the public can easily access and gain information in the form of digital information products, including music works. However, this causes copyright infringement because it is often ignored.

Basically, the holders and owners of Copyright in the field of digital music have the right to freely control their IPR by using agreement to set conditions for anyone who uses their intellectual creations. This is because the intellectual creations concerned are prone to infringement and forgery.

The emergence of the music industry is expected to generate profits. As for the loss of Royalties, especially on paid and free services, this is part of the infringement and forgery of copyrighted works.

The way royalties are calculated has a gap where the holders of the related rights get a larger amount than the creators. This of course makes songwriters not get royalties in accordance with the mandate of the Copyright Law (UUHC) where the creators should have the economic rights to a work, including distributing it into digital music services

Based on the background of the problem above, the research problem proposed is how the implementation of the Copyright Law in the field of digital music and the enforcement of the law of infringement and forgery with the emergence of the digital music industry are for the sake of justice, legal certainty and legal benefits for music creators. 


\section{RESEARCH METHOD}

This research used a normative juridical approach. It focused on the enforcement of normative legal provisions in action on every particular legal event that occurs in society ${ }^{11}$ by examining theoretical matters concerning principles, conceptions, views, legal doctrines and laws and regulations.

Primary data were obtained from online research resource using the Zoom Meeting application, consisting of: 1). The Directorate General of Intellectual Property; 2). Academicians 3). Song and music creators. 4). Representatives of Collective Management Organization. The reason for the selection of the resource persons is that the resource persons are the implementers and experts in the field of copyright of music. Secondary data were obtained through literature review and review of secondary legal materials in the form of books, journals, related research results and papers relevant to the research problem.

This research is descriptive analytical with qualitative analytical method which aims to describe the actual conditions in the field by systematically, factually and accurately describing the facts, nature and relationships between the phenomenon and data that have been collected. ${ }^{12}$

\section{DISCUSSION AND ANALYSIS}

Enforcement of Law of Copyright Infringement and Forgery with the Rise of the Digital Music Industry

\section{Implementation of Copyright Law in the Field of Digital Music}

Based on Law No. 28 Year 2014 concerning Copyright (UUHC), it is stated that copyright is the exclusive right of a creator that arises automatically based on declarative principles after a work is manifested in a tangible form without reducing the restrictions pursuant to the provisions of laws and regulations ${ }^{13}$.

" Abdulkadir Muhammad, Hukum Dan Penelitian Hukum, (Bandung: Citra Aditya Bakti, 2004), h.134.

12 F.L. Whitney, The Elements of Research, (New York: Prentice Hall Inc., 1960), Hlm. 204

13 "Siapa Pencipta dan Siapa Pemegang Hak Cipta?". Hukum Online. Last modified 12 Februari 2019. https:// www.hukumonline.com/klinik/detail/ulasan/cl655/ siapa-pencipta-dan-siapa-pemegang-hak-cipta/ dikases pada tanggal 5 Februari 2021
In exclusive rights, there are economic rights and moral rights. Economic rights are the rights to use a work for commercial purposes with the aim of obtaining economic benefits from a work. Moral rights are rights that are absolute and inherent in the creators of songs and music, including music that is disseminated on social media, both for commercial and non-commercial purposes, which include economic rights and related rights ${ }^{14}$.

The use of digital music on social media without the permission of the creator or owner of the related rights for commercial purposes is a form of infringement of copyright in the form of license. The regulation and protection of economic rights and moral rights to music on social media have been regulated in Article 12 to Article 15 of the Copyright Law. Moral rights are regulated in Article 5 to Article 7 of the Copyright Law. Although the regulation of economic rights and moral rights has been regulated in the Copyright Law, many infringements of Copyright are still being committed. This is influenced by the regulation of complaint offense made by the holder of related rights. As long as there are no complaints from the creators or owner of the related rights, infringements are rarely reported ${ }^{15}$.

Moral rights are rights that are eternally attached to the creators, such as the right to keep or not to keep their names on the copy in connection with the public use of their works, the right to use their original name or pseudonym, the right to modify their works in accordance with the decency in society, the right to change the title and sub-title of their works, the right to defend their rights in the event of distortion, mutilation, or modification of the works or things that are detrimental to their honor and reputation ${ }^{16}$. These efforts to develop creativity are carried out in order to create original works in accordance with their productivity by taking into account the Copyright Law.

If the creators transfer their copyright to someone else, that person will get economic benefits. Nevertheless, the moral rights will remain

14 Agus, Zoom Meting opini balitbang hukum dan HAM 15 oktober 2020

15 Desyanti Suka Asih K.Tus, "Hak Ekonomi Dan Hak Moral Karya Cipta Potret Di Sosial Media," Vyavahara Duta 14, no. 1 (2019): 12.

16 Fajar Alamsyah," Perlindungan Hukum Terhadap Hak Cipta Menurut Pasal 12 Undang-Undang No. 28 Tentang Hak Cipta di Indonesia”, JOM Fakultas Hukum Vol .III No. 2 (2016). Hlm. 2-3. 
attached to the creators because these moral rights cannot be removed or abolished. Thus, it is clear that economic rights can be transferred to other parties by the creators, while moral rights remain attached to the creators ${ }^{17}$. One cannot alter nor change the title and/or content of the work. However, this can be done with the permission of the creators or their heirs if the creators have died, including licenses that have been held ${ }^{18}$.

Any person who exercises economic rights must obtain permission from the creator or copyright holder. Any person without the permission of the Creator or Copyright Holder is prohibited from duplicating and/or commercially using the works. In the previous Copyright Law, copyright protection was for 50 years, however, copyright protection in the current Copyright Law is for 70 years. This can be interpreted that there is an improvement in the protection of the moral rights of the creators ${ }^{19}$. The provision of this protection attempt means providing an opportunity for the creators to be able to enjoy their works in order to improve the economic rights of the creators $^{20}$.

According to the declarative principle, a work is realized in a tangible form without reducing the restrictions pursuant to the provisions of laws and regulations. In this case, what is meant by exclusive rights is that only the creator and the right holder who are free to exercise the copyright, while other people or other parties are prohibited from exercising the copyright without the copyright holder's approval.

The exclusive rights owned by the copyright holder are not absolutely and fully owned because there is a limitation where someone who wants to use or utilize the work of the creator does not need permission to use it as long as it does not harm the reasonable interests of its use. This is known as the "fair use" principle ${ }^{21}$.

${ }_{17}$ Yngvar Kjus, "The Use of Copyright in Digital Times: A Study of How Artists Exercise Their Rights in Norway," Popular Music and Society 7766 (2019).

18 Desyanti Suka, "Hak Ekonomi dan Hak Moral Karya Cipta Potret di Sosial Media”, Fakultas Dharma Duta Vol. XIV No.1 Maret (2019), hlm. 15.

19 Sartika Nanda L, "Perlindungan Hak Moral Pencipta di Era Digital di Indonesia", Jurnal Universitas Diponegoro.hlm. 4-8.

${ }_{20}$ Marsel siahaan, Zoometing 15 oktober 2020

${ }_{21}$ Ziana Mahfuzzah, "Duties And Authorities Of The Collective Management Institute (LMK) As The
This often results in many musical works/ songs being easily modified by others and actually causes harm to the creator or copyright holder ${ }^{22}$. The owner's rights to copyrighted works do not necessarily make a person monopolize and enrich themselves on the economic rights that have been obtained. To balance the rights of the owner with the interests of society, the Copyright Law allows the use of certain works without the permission of the creator ${ }^{23}$.

Regarding the differences in copyright in addition to the fair use category, there are also four factors to determine the use of a work (song) based on fair use, namely, the purpose and character of use, the nature of the protected copyrighted work, the number and important parts used in the whole work, and the effect of use that can harm the creator or copyright holder. Factors and indicators like these are not regulated in the Copyright Law, including regulations related to the amount of royalties. This is because the amount of royalties is only in the form of an agreement between the creator and the owner of the related rights in digital media ${ }^{24}$.

The Copyright Law and the derivatives of Regulation of the Minister of Law and Human Rights have specifically regulated the amount of royalties from 26 places/media including restaurants, cafes, music concerts, exhibitions, cinemas, television broadcasting institutions, radio and hotels in 2021. This was marked by the issuance of Government Regulation (PP) No. 50 Year 2021 concerning Management of Song and/or Music Copyright Royalties relating to Collective Management Organization (LMK), royalties and song and/or music data center.

To guarantee the protection and legal certainty of the economic rights of Creators, Copyright Holders, and owners of Related Rights on songs and/or music, it is necessary to have a royalty management mechanism that is transparent, quality, and on target as well as through the means of information technology.

Royalty Management Institution For Song And Music Included In Digital Music Services" 3, No. 02 (2020): 251-255.

22 Nanda Reza Putra Pratama, Zenny Rezania Dewantary, "State's Legal Protection To Copyright Holders Of Songs In Relation To The Online Songs Piracy" (2018). Jurnal Universitas Presiden

23 Undang-Undang Republik Indonesia Nomor 28 Tahun 2014 Tentang Hak Cipta, 2014.

24 Ibid. 
The management of royalties shall be carried out by the National Collective Management Organization as an authorized institution based on the Law which represents the interests of the Creators and the owners of the Related Rights to charge, collect, and distribute royalties from people who use the works commercially.

Based on Article 1 paragraph (2) of Copyright Law, royalty is a reward for the utilization of economic rights of a work or product of related rights received by the creator or owner of the related rights. Payments are made by users of copyrights or related products to the creators and/ or the holders of related rights in connection with the granting of permission to exploit or use the related works or products ${ }^{25}$.

The amount of payment of a royalty is generally determined based on an agreement with a certain portion. Then, this is stated in the form of a written agreement or deed.

Creators or Copyright Holders have limitations in turning their works into money. In this case, the creator needs the role of another party to transfer all or part of his/her economic rights to another party in the form of a license.

Creators who own music works can grant a license to a music label to promote their songs or music so that they are known by the public and have high economic value from streaming the music ${ }^{26}$.

The streaming music applications such as Joox, Spotify and YouTube are a new breakthrough for the music world where music listeners are given the convenience of accessing the music offered, including for the millennial generation at this time ${ }^{27}$. Only by downloading the applications via a smartphone, listeners can enjoy the music they want without limits. The listeners do not have to buy dozens of cassettes or CDs at much higher prices. In this case, the data obtained in each song streaming is a royalty that is obtained and collected

25 Lawrence M. Shindell, " Provenance and Title Risks in the Art Industry: Mitigating These Risks in Museum Management and Curatorship," Museum Management and Curatorship 31, no. 5 (2016): 406417.

${ }^{26}$ Agus, Opini balitbang Hukum dan HAM Zoometing 20 Oktober 2020

${ }_{27}$ Kristin McGee, "Biopolitics and Media Power in the Online Dance Remake: Remixing Beyoncés ‘***Flawless' in the YouTube Archive," Popular Music and Society 42, no. 1 (2019): 22-41. through the streaming music applications ${ }^{28}$.

According to the Global Web Index Coronavirus Research Report data, the "Digital Media Use during Covid-19" is as follows: Gen Z (ages 16-23): music streaming; Millennials (2437): online videos, YouTube, TikTok; Gen X (ages 38-56): traditional TV, online video; and Boomers (ages 57-63): traditional $\mathrm{TV}^{29}$. This indicates that streaming services are most in demand by the productive ages with the most internet service use.

However, according to the Copyright Law, there is a party authorized to collect and distribute royalties, namely the Collective Management Organization. This is stated in Article 1 number 22 of the Copyright Law which states that a Collective Management Organization is an institution in the form of a non-profit legal entity that is authorized by the Creators, Copyright Holders, and/or owners of Related Rights to manage their economic rights by charging, collecting and distributing the royalties.

The Collective Management Organization itself is regulated separately in Chapter XII of Article 87 to Article 93 of the Copyright Law. The Collective Management Organization is a nonprofit legal entity authorized to collect fees from users who utilize Copyright and Related Rights in the form of commercial public services. The users pay a royalty to the Copyright Holder or Owner of the Related Rights through the Collective Management Organization. Once the royalties are collected, the Organization is obliged to distribute the royalties to Copyright Holders or Owners of the Related Rights ${ }^{30}$.

In its development, the Collective Management Organization (LMK) was first recognized in Indonesia with the establishment of Karya Cipta Indonesia (KCI) with the aim of assisting musicians in enforcing the rights, namely the right to announce and the right to reproduce by collecting royalties. Referring to Article 87 paragraph (1) of Copyright Law, a

${ }_{28}$ Antonio Rajoli G, "Peran Lembaga Manajemen Kolektif Nasional Dalam Perkembangan Aplikasi Musik Streaming”, Pusat Pengkajian dan Pengembangan Kebijakan Badan Penelitian Dan Pengembangan Hukum Dan Hak Asasi Manusia Kemenkumham Vol.13 No.3 November (2019). Hlm. 383-386.

29 Visual Kapitalis.Com "Global Web Index Coronona Reasech Report" April 2020

3o Undang-Undang Republik Indonesia Nomor 28 Tahun 2014 Tentang Hak Cipta. 
creator, copyright holder and owner of related rights shall become a member of CMO in order to be able to charge reasonable fee from users who utilize the copyright and related rights in the form of commercial public services with the aim of providing protection for creators and owners of the related rights.

In its implementation, according to Article 88 of the Copyright Law, CMO must have an operational permit issued by the Ministry of Law and Human Rights. This means that unlicensed $\mathrm{CMO}$ members are prohibited from charging, collecting and distributing royalties. In Article 40 of the Copyright Law, there are several protected works, namely in the fields of science, art and literature.

If the creators have difficulty in getting money from their works, they can register themselves and their works to become a member of CMO first. The creators can charge a reasonable fee in the form of royalties if the creators want to exercise their copyright in the form of a commercial public service.

In Article 1 of the Regulation of the Minister of Law and Human Rights No. 36 Year 2018 concerning Procedures for Application and Issuance of Operational Permits and Evaluation of Collective Management Organization, it is explained that the National Collective Management Organization (LMKN) is a nonState Budget government aid agency that has attributive authority from the Copyright Law to charge, collect and distribute royalties and manage the economic rights interests of the Creators and Owners of the Related Rights in the field of songs and/or music ${ }^{31}$.

Based on this explanation, it is clear that those who is entitled to charge royalties is the $\mathrm{NCMO}^{32}$. Prior to the issuance of this regulation, the charge of royalties and distribution of royalties on songs and music which were used only for business purposes were carried out by CMO. However, after the issuance of the aforesaid regulation, the Ministry of Law and Human Rights (Kemenkumham) together with the National Collective Management Organization (LMKN) and 8 (eight) Collective

\footnotetext{
${ }^{31}$ Masela Saihaan, Zoom Meeting Opini balitbang Hukum dan HAM 20 Oktober 2020

32 Jamilus" Optimalisasi Mediasi Kekayaan Intelektual Di Kementerian Hukum Dan Ham” Jurnal Penelitian Hukum De Jure, Vol. 20 No. 1, Maret 2020
}

Management Organizations (LMK) such as Karya Cipta Indonesia (KCI), Wahana Musik Indonesia (WAMI), Persatuan Artis Penyanyi Pencipta Lagu dan Musik (PAPPRI), Sentra Lisensi Musik Indonesia (SELMI), Anugrah Royalti Musik Indonesia (ARMINDO) and Star Musik Indonesia (SMI) agreed to collect music royalties in a onestop system, namely NCMO.

In this case, NCMO is the only body that has the authority to charge, collect and distribute royalties from commercial users in order to realize professional, transparent, fair and efficient management of music royalties ${ }^{33}$.

In this digital era, the pattern of music distribution has shifted from physical media to digital media. This shift gives rise to a new role in the pattern of music distribution, namely Music Aggregator. Music Aggregators are intermediaries between musicians or creators with digital music stores and online music streaming platforms in the digital distribution of copyrighted works, both songs and music, to both platforms. The Role of Music Aggregators is important in the digital distribution of music ${ }^{34}$.

There are several things that can be a reason why Music Aggregator cannot be categorized as a CMO. This is because basically what is carried out by the Music Aggregator emphasizes the three basic tasks of CMO, namely charging, collecting and distributing royalties. The Music Aggregator is authorized to distribute, publish, and duplicate the copyrighted works, collect and manage royalties of the copyrighted works of songs and music that are accounted for to them so that they can be distributed to online music streaming platforms and digital music stores. Music Aggregators can offer services broadly to creators and act freely of their own free will because they are not yet regulated by law. This is because basically Music Aggregator is an entity or individual who seeks profit on services. Music Aggregator is different from $\mathrm{CMO}$ because $\mathrm{CMO}$ is a non-profit body under the auspices of the state

33 Rintami Njatrijani, Herni Widanarti, Mutia Adiva, "Era Digital Melahirkan Peran Baru, Aggregator Musik Dalam mendistribusikan Karya Cipta Lagu dan Musik", Fakultas Hukum Universitas Diponegoro Vol.7 No.1 Februari (2020). hlm. 694-697

34 Rinitami Njatrijani, Fakultas Hukum, and Universitas Diponegoro, "Era Digital Melahirkan Peran Baru, Aggregator Musik Dalam Mendistribusikan Karya Cipta Lagu Dan Musik" Vol 7 No.1 (2020): 689-699. 
that carries out tasks in accordance with the law and is responsible to the NCMO and the Ministry of Law and Human Rights ${ }^{35}$.

Even though there is similarity, Music Aggregatorcannotbeclassifiedas CMO.Therefore, it is necessary to make efforts to revise the laws and regulations to suit current conditions. This is because the Copyright Law and Regulation of the Minister of Law and Human Rights No. 29 Year 2014 concerning Procedures for Application and Issuance of Operational Permits and Evaluation of the National Collective Management Organization state that there is possibility for anyone to form a $\mathrm{CMO}$ with certain conditions. Moreover, this can be done in order to facilitate individual businesses in establishing business entities in order to develop the music industry in Indonesia.

In practice, the role of the music aggregator is to apply the principles of agreement in good faith and fulfill the legal terms of the agreement. Therefore, the good and complete fulfillment of rights of the creator can serve as the basis for the obligations and authority to carry out its function as a music distributor in the digital realm.

This is expected to minimize the occurrence of negligence in carrying out obligations or damage to rights. Things that can be done to avoid the occurrence of a problem, both for creators and Music Aggregators, are to tighten the song registration system in the distribution of music by aggregators in order to minimize piracy, clear rules regarding the operational permit of a Music Aggregator and rules regarding limit of authority and duties of a Music Aggregator ${ }^{36}$.

In Government Regulation Number 56 Year 2021 concerning Management of Royalties for Song and Music Copyrights, it is stated that comprehensive Royalty Management needs to be supported by information technology facilities. Thisislikea song and/or music data center managed by the Directorate General of Intellectual Property and SILM (Song and/or Music Information System) managed by the NCMO.

35 Agus, Opini balitbang Hukum dan HAM 20 oktober 2020

${ }^{36}$ Sartika Nanda Lestari and Arifin Pringgo Laksono, "A Legal Protection of Music Royalty on Open Content License through Soundcloud," Jurnal Dinamika Hukum 18, no. 3 (2018): 329-336, http:// dinamikahukum.fh.unsoed.ac.id/index.php/JDH/ article/view/2124/616.
The song and/or music data center as a data set of songs and/or music is the basis for both the NCMO in Royalty Management and people who use it commercially to obtain information from songs and/or music that will be used commercially. Meanwhile, the Song and/or Music Information System is an information system used in the distribution of Royalties for songs and/or music.

Registration of songs and/or music shall be done through an application. Application for registration of songs and/or music shall be submitted electronically to the Minister of Law and Human Rights by the Creator, Copyright Holder, owner of the Related Rights, or Proxy. For submission of an application for registration of songs and/or music by a Proxy, it can be made by NCMO based on the power of attorney from the Creator, Copyright Holder, or owner of the Related Rights. Songs and/or music are registered in the general register of Works.

In collecting Song and/or Music Royalties, the NCMO shall coordinate and determine the amount of Royalty that is the right of each CMO in accordance with the prevalence in practice based on justice. Royalties that have been collected by the NCMO shall be distributed by the NCMO based on reports on the use of song and/or music data in the Song and/or Music Information System. In the event of a dispute regarding the discrepancy in the distribution of the amount of Royalty, the Creator, Copyright Holder, and owner of the Related Rights, the Creator may submit the matter to the Directorate General for settlement by mediation ${ }^{37}$. This indicates that mediation efforts are important to be implemented first.

\section{The Enforcement of Law of Copyright Infringement and Forgery with the Rise of the Digital Music Industry}

Digital technology-based media has now entered various segments of human activity in almostall parts of the world. The era of globalization and digital has developed so rapidly, especially its influence on the field of work/human activity. With various advantages and conveniences, the Internet turns out to not only provide benefits to business actors, but also cause losses that have an impact on unlawful acts such as data security and

37 Peraturan Pemerintah Republik Indonesia Nomor 56 Tahun 2021 tentang Pengelolaan Royalti Hak Cipta Lagu dan Musik 
privacy, legal protection of human rights owned by everyone who has copyright in the field of digital music.

Advances in digital technology have had an impact on increasing copyright infringement in Indonesia, especially for digital copyrighted works in the form of computer software, digital music, digital films, e-books, and others. In Indonesia, internet users have reached 39 million people. Around $12 \%$ of internet users use the internet as a medium for transacting. The ease of using digital media through social media is not a strange thing. However, the trend of "crime" is also increasing. This is because it is not easy to carry out law enforcement of intellectual property in the field of copyright of online digital music ${ }^{38}$.

According to a DailySocial report, a research on digital media use was carried out through a survey of music streaming service in 2018 in collaboration with Jakpat through a mobile survey platform. The number of respondents was 955 people from various regions in Indonesia. Some of the interesting findings in the survey include ${ }^{39}$ :

1. $52 \%$ of the respondents subscribed to paid music streaming services

2. $56.12 \%$ of the respondents used music streaming services from free access from mobile phone service providers

3. The most widely used paid music streaming service was JOOX, which was used by $70.37 \%$ of the respondents.

4. $85 \%$ of the respondents listened to online music streaming regularly in the last six months.

This pandemic situation has pushed musicians to rely more and more on music streaming applications such as YouTube, Spotify, Joox, and others. These platforms make music distribution much easier and reach more music lovers. However, unlike physical releases, digital musical works carry a greater risk of copyright infringement. The dominance of digital music also brings a new challenge, namely the calculation of

\footnotetext{
38 Lestari and Laksono, "A Legal Protection of Music Royalty on Open Content License through Soundcloud."

39 Laporan DailySocial: Survei Layanan Streaming Musik 2018, https: //dailysocial.id post/laporan-dailysocialsurvei-layanan-streaming-musik-2018, diakses tanggal 5 September 2018
}

music royalties from digital platforms ${ }^{40}$.

Since the past, the issue of royalties has been a problem for creators or holders of copyright and related rights in the music industry in Indonesia. If the creator of the song or music does not have access to all uses of their song creation after the sound recording, automatically, the copyright owner does not get economic benefits from people who use the song or music for commercial purposes. Based on this problem, the role of Collective Management Organization (CMO), Performing Right Society (PRS), and Collecting Society $(\mathrm{CS})$ is needed.

The Minister of Law and Human Rights Yasonna Laoly says that the collection of royalties on intellectual property rights belonging to Indonesian artists from sites such as YouTube, Facebook, and Google could be a new source of foreign exchange. Currently, Indonesia is only able to collect royalties of around Rp. 20 billion for IPR circulating on various sites in cyberspace. This is different from Malaysia, which can collect Rp. 300 billion. In fact, there are far more internet users in Indonesia than Malaysia ${ }^{41}$.

The presence of $\mathrm{CMO}$ is intended to bridge the interests of creators, holders of copyright and holders of related rights on the one hand so that their economic rights can be fulfilled and the interests of commercial song or music users on the other hand can be exploited more easily. The purpose of establishing CMO is to realize the welfare of creators and holders of related rights to support national economic development. When a creator joins or enters a CMO, administratively, he/she will submit a letter of transfer, which is a mandate or license to administer the management of his/her rights.

The CMO has the right to issue licenses for those who aim to make use of the copyrighted works licensed to them. However, the number of piracy of music will increase rapidly. Songs are objects that are given copyright and are objects of the Copyright Law. Online song piracy is

\footnotetext{
$4^{\circ}$ Jesi Andreanto and Anak Agung Sri Utari, "Mekanisme Pembayaran Royalty Fee Berkaitan Dengan Cover Lagu Dalam Media Sosial", Jurnal Universitas Udayana Vol.8,No.1(2019) : 1-12.

41 “Spotify Kena Gugat Rp 21,6 Triliun, Kenapa?",Detik Last modified 3 Januari 2018, accessed 5 Februari 202, https://inet.detik.com/cyberlife/d379704o/spotifykena-gugat-rp-216-triliun
} 
detrimental to songwriters, singers, music labels and other related parties. This irresponsible behavior is hard to stop because it is done online, it is free, and people can still pirate music online even if it has been blocked. This situation raises question on how the Government of Indonesia provides protection and preventive measures against online song piracy ${ }^{42}$.
In addition to the advantage, there is disadvantage for creators where royalties from this music streaming service are still relatively small. The royalties received by the artists also depend on their popularity. The distribution also depends on the company's provisions. The average royalty from various digital music services is US\$ 0.0111 per song played. This figure is clearly a small figure for Indonesian musicians considering that Indonesian music listeners are actually only limited to Indonesia and several neighboring countries $^{43}$.

Figure 1

\section{Business Process of Spotify Music service}

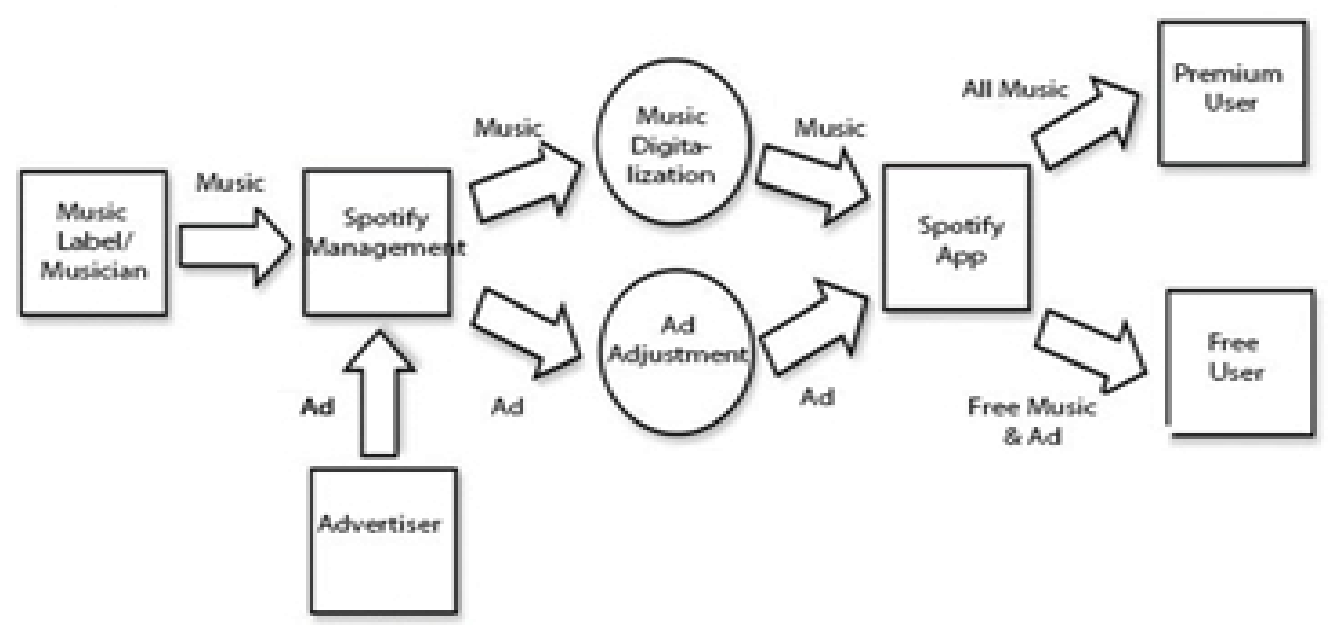

Figure 2

Digital Interactive Service Music Royalty (paid)

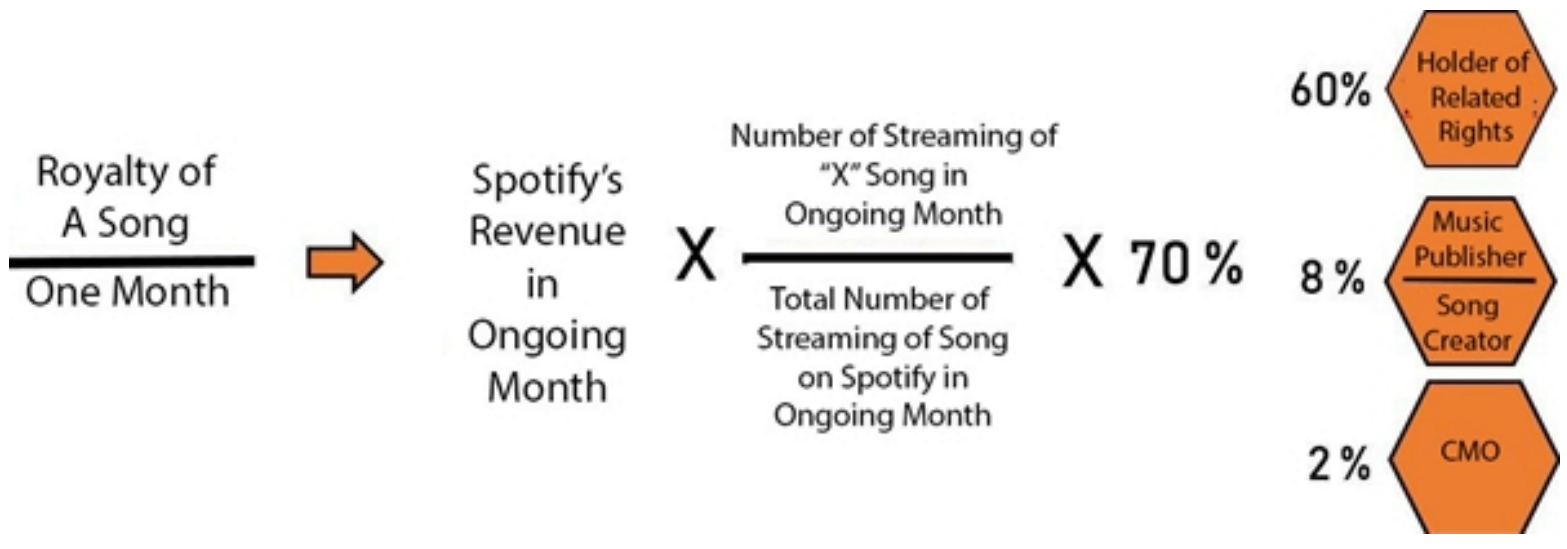

42 Nanda Reza Putra Pratama, Zenny Rezania Dewantary Pratama, "State's Legal Protection To Copyright Holders Of Songs In Relation To The Online Songs Piracy Nanda” (n.d.).

43 Streaming Musik, Saat Bajakan Mulai Ditinggalkan oleh Rizqa Lahuddin, https://www.kompasiana.com/ kotakireng/592f969462afbd470c5261ab/streamingmusik-saat-bajakanmulai-ditinggalkan di akses tanggal 12 Agutus 201 
Figure 3

Non-interactive Service (Free)

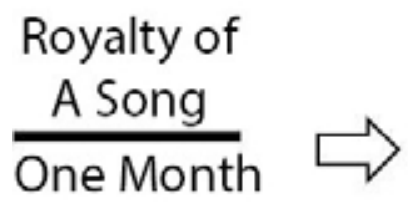

Source ${ }^{44}$ : Ziana (2019)

Based on the figures above, it is explained that there are two business processes for Spotify's music service, namely the paid one which has the Digital Interactive Service Music Royalty (paid) and the free one. These two processes lead to very different consequences when it comes to awarding royalties in Indonesia

When viewed based on the pattern of use, there are $70 \%$ of royalties given to musicians through the use of premium or paid access and $2 \%$ of royalties given to musicians through the use of free access.

This case is rife in the digital era where music users use the Spotify site as an internet site that provides various kinds of music content. Currently, many streaming service users upload videos using background song without citing the source of the song. To find out the copyright protection against the use of songs as background sound in videos on the YouTube site, we can refer to the Copyright Law where there are legal remedies that can be taken against the use of songs as background sound in videos ${ }^{45}$.

The protection of copyrighted works, especially music as the background sound for videos uploaded on the YouTube site, has actually been regulated in Article 5 and Article 9 of the Copyright Law. In addition to the Copyright Law, YouTube also provides copyright legal protection by granting a license. Through this license, copyright holders can claim Content ID if there is an infringement in the use of material protected by copyright. The creator can take preventive legal measures and repressive efforts in the event of an

\footnotetext{
44 Ziana Mahfuzzah, "Tugas Dan Wewenang Lembaga Manajemen Kolektif (LMK) Sebagai Pengelola Royalt Atas Lagu Dan Musik Yang Dimuat Dalam Layanan Musik Digital," 2019.

45 Lestari and Laksono, "A Legal Protection of Music Royalty on Open Content License through Soundcloud."
}

\section{Total Revenue of Digital Music Service Provider from Advertising Total Number of Songs
played in the platfrom}

infringement of his/her creation ${ }^{46}$.

Article 18 paragraph (1) of Law Number 8 Year 1999 concerning Consumer Protection (UUPK) states that the purpose of the prohibition on the inclusion of standard clauses is to place the recipient on an equal footing with the bidder based on the principle of freedom of contract as regulated in Article 1338 of the Civil Code (KUHPer). Article 18 paragraph (1) of the Consumer Protection Law regulates in detail what standard clauses are prohibited from being included in an agreement so that if the clauses are found in an agreement, the agreement can be canceled by the receiving party.

The emergence of an agreement between the Music Aggregator and the creator or copyright holder results in the granting of authorization for the copyrighted work created by the creator to the aggregator to act on the copyrighted work on himself (the creator) in carrying out this digital distribution activity ${ }^{47}$. The limitation of the responsibility of a Music Aggregator is still limited to the agreement made between the aggregator and the creator or copyright holder, because the laws and regulations have not further regulated. In the agreement between the Copyright Owner and the Music Aggregator, these two parties act to carry out their obligations so that the rights of both parties are fulfilled. If one of the parties is negligent in fulfilling their rights and carrying out their obligations, a dispute may occur.

In addition, in the event of a dispute, the settlement is carried out based on the role of the Music Aggregator as a business actor and the creator or a copyright holder as a consumer

\footnotetext{
${ }^{46}$ Desak Komang, "Perlindungan Hak Cipta Terhadap Pengguanaan Lagu Sebagai Suara Latar Video Di Situs Youtube",Jurnal Hukum Bisnis Fakultas Hukum Universitas Udayana Vol. 07, No. 10, Juli 2019

47 Mahfuzzah, "Duties And Authorities of The Collective Management Institute ( LMK ) As The Royalty Management Institution For Song and Music Included in Digital Music Services."
} 
based on Law Number 8 Year 1999 concerning Consumer Protection. Basically, the Law has provided equality of position between consumers and business actors, but the concept of consumer protection as a necessity must always be disseminated to achieve the principle of fair equality and to balance the activities of business actors who carry out economic principle that is to get maximum profit with minimum capital ${ }^{48}$.

Law Number 8 Year 1999 concerning Consumer Protection divides dispute settlement into two categories, namely: Settlement of disputes through courts, Settlement of disputes through amicable resolution by the parties themselves, namely consumers and business actors/producers; Dispute settlement through the Consumer Dispute Resolution Agency using alternative dispute resolution (ADR) mechanisms, namely reconciliation, mediation and arbitration. Dispute settlement out of court is held to reach an agreement on the form and amount of compensation or regarding certain actions so that consumers will not experience it. This is done to bring the formulation of a solution that contains a dispute settlement ${ }^{49}$.

According to the Digital Economy Report, high levels of infringement and forgery of IPR can reduce people's income and investment levels. Constraints in the complex law enforcement related to IPR are influenced by regulations, such as complaint offenses that hinder the law enforcement. The coordination process between the Civil Servant Investigators of Directorate General of Intellectual Property and other law enforcement officers needs to be improved both in terms of supervision and law enforcement, such as payment of compensation, termination of certain activities that cause consumer losses, obligation to withdraw from circulation, to the last resort of ultimum remedium in the form of criminal sanctions.

\footnotetext{
${ }^{48}$ Rusli, T "Penyelesaian Sengketa Antara Konsumen dan Pelaku Usaha Menurut Peraturan PerundangUndangan",Jurnal Keadilan Progresif Volume 3,Nomor 1 Maret 2012

49 Donald Henry" Penyelesaian Sengketa Hak Kekayaan Intelektual Melalui Acara Cepat" Jurnal Penelitian Hukum DE JURE, Vol. 17 No. 1, Maret 2017
}

Graph

Copyright Disputes from 2015-2019

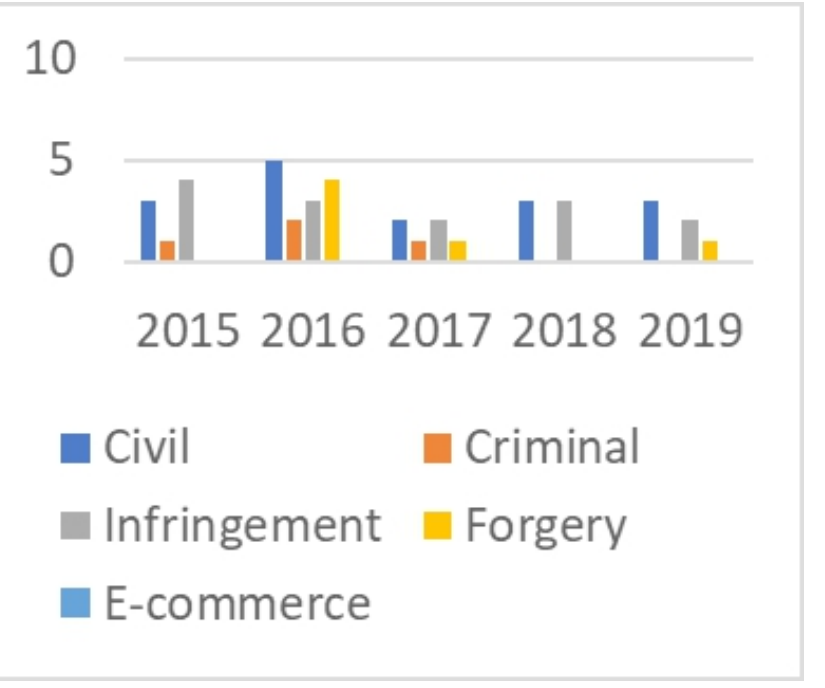

Source: Directorate General of Intellectual Property 2020

The sheer volume and speed of online forgery makes online listings particularly sensitive to law enforcement. However, various efforts have been made, including law enforcement by the Civil Servant Investigators of Directorate General of Intellectual Property, the Police and the Court. This can be seen from the number of court decisions that show improvement in the enforcement of IPR law, including the mechanism for supervising copyright in the digital music sector.

Internally,itisnecessarytoprepareinstitutions and judicial officers who have the competence and ability to decide IPR cases that contain jurisdictional conflicts or in the case of a choice of law ${ }^{50}$. In addition, it is necessary to improve the understanding of IPR consultants in the field of copyright so that they can provide assistance to IPR cases with national and international dimensions. In addition, there needs to be an improvement in the understanding of law enforcement officers, namely the police, prosecutors and judges so that they are able to carry out extraterritorial IPR enforcement, including the mediation mechanism contained in Government Regulation No. 56 Year 2021 concerning Management of Royalties for Song and Music Copyrights.

Commonly, lawsuits for copyright infringement can be brought to court. If one

50 Rami Jened, "Konflik Yurisdiksi Dan Penegakan Hukum Kekayaan Intelektual Dalam Pasar Tunggal" Volume 28, no. Mimbar Hukum (2016): 201-214. 
wants to save on court costs, alternative dispute resolution can be made, namely litigation and non-litigation, both of which are regulated in Article 95 of the Copyright Law. Indonesia has laws and regulations regarding dispute resolution by non-litigation, namely Law Number 30 Year 1999 concerning Alternative Dispute Resolution and Arbitration. In Article 1 of the Law, it is explained that the alternative resolution is dispute resolution through a procedure agreed upon by the parties. In other words, non-litigation dispute resolution requires an agreement by both parties by means of mediation, reconciliation, negotiation, consultation or expert judgment.

\section{CONCLUSION}

With the emergence of the digital music industry, the enforcement of law of infringement and forgery can be carried out with litigation and non-litigation for justice, legal certainty and legal benefits for music creators. The mediation process as in Government Regulation No. 56 Year 2021 concerning Management of Royalties for Song and Music Copyrights needs to be made amicably so that justice, legal certainty and legal benefits can be achieved. However, efforts are needed to improve regulations related to complaint offense against copyright, which state that there will be legal proceedings only if there are complaints from applicants or creators or owners of related rights. Basically, this regulation often causes legal uncertainty because forgery and infringement would be easier to commit.

Efforts to take repressive and preventive action must be carried, such as payment of compensation, termination of certain activities that cause harm to creators and owners of related rights, obligation to withdraw from circulation, revocation of business licenses, termination of business activities and the last resort of ultimum remedium in the form of criminal sanctions.

\section{SUGGESTION}

Efforts to improve the existing music database in Indonesia need to be done to find out the number and owners of copyrights and related rights in the digital music field comprehensively. This must be done to avoid copyright infringement and forgery in the field of digital music. The National Collective Management Organization (NCMO) needs to immediately establish a fair, transparent and accountable mechanism and regulation of digital service royalty rates. Coordination and improvement of competence of law enforcement officers in the field of IPR needs to be improved so that they have the ability and integrity of law enforcement against infringement and forgery in the field of IPR. Knowledge and understanding related to the Copyright Law and its derivative regulations, including Government Regulation No. 56 Year 2021 concerning Management of Royalties for Song and Music Copyrights need to be improved to avoid the number of infringement and forgery that can harm various parties, including the state. The dissemination of information carried out by the government is part of the legal protection of the community to increase the public legal awareness in the digital and global era.

\section{ACKNOWLEDGMENT}

This paper is the result of an actual research by the Research and Development Board for Law and Human Rights. Thus, the researcher would like to thank, especially, the Head of the Research and Development Board for Law and Human Rights, the Head of the Legal Research and Development Center as well as the resource persons and related parties.

\section{BIBLIOGRAPHY}

Andreanto, Jesi, And Anak Agung Sri Utari. "Mekanisme Pembayaran Royalty Fee Berkaitan Dengan Cover Lagu Dalam Media Sosial" (2014): 1-12.

Behr, Adam, Keith Negus, And John Street. "The Sampling Continuum: Musical Aesthetics And Ethics In The Age Of Digital Production." Journal For Cultural Research 21, No. 3 (2017): 223-240. Http://Doi.Org/1 0.1080/14797585.2017.1338277.

Donald, Henry" Penyelesaian Sengketa Hak Kekayaan Intelektual Melalui Acara Cepat" Jurnal Penelitian Hukum DE JURE, Vol. 17 No. 1, Maret 2017

Ginting, Ar, "Peran Lembaga Manajemen Kolektif Nasional Dalam Perkembangan Aplikasi Musik Streaming”, Jurnal Ilmiah Kebijakan 
Hukum Vol 13, No.3, November 2019, P.379-398

Jamilus" Optimalisasi Mediasi Kekayaan Intelektual Di Kementerian Hukum Dan Ham" Jurnal Penelitian Hukum De Jure, Vol. 20 No. 1, Maret 2020

Jened, Rahmi. "Konflik Yurisdiksi Dan Penegakan Hukum Kekayaan Intelektual Dalam Rangka Pasar Tunggal." Mimbar Hukum - Fakultas Hukum Universitas Gadjah Mada 28, No. 2 (2016): 201.

Kjus, Yngvar. "The Use Of Copyright In Digital Times: A Study Of How Artists Exercise Their Rights In Norway." Popular Music And Society 7766 (2019).

Kusmayanti, Rita. "Perbandingan Hukum Hak Cipta Fotografi Tanpa Izin Pencipta Di Indonesia Dan Amerika" 2, No. 2 (2018): 274-284.

Lestari, Sartika Nanda, And Arifin Pringgo Laksono. "A Legal Protection Of Music Royalty On Open Content License Through Soundcloud." Jurnal Dinamika Hukum 18, No. 3 (2018): 329-336. Http:// Dinamikahukum.Fh.Unsoed.Ac.Id/Index. Php/Jdh/Article/View/2124/616.

Mahfuzzah, Ziana. "Duties And Authorities Of The Collective Management Institute ( Lmk) As The Royalty Management Institution For Song And Music Included In Digital Music Services" 3, No. 02 (2020): 251-255.

—. "Tugas Dan Wewenang Lembaga Manajemen Kolektif ( Lmk ) Sebagai Pengelola Royalti Atas Lagu Dan Musik Yang Dimuat Dalam Layanan Musik Digital," 2019.

Mcgee, Kristin. "Biopolitics And Media Power In The Online Dance Remake: Remixing Beyoncé's '***Flawless' In The Youtube Archive." Popular Music And Society 42, No. 1 (2019): 22-41.

Njatrijani, Rinitami, Fakultas Hukum, And Universitas Diponegoro. "Era Digital Melahirkan Peran Baru, Aggregator Musik Dalam Mendistribusikan Karya Cipta Lagu Dan Musik" Vol 7 No.1 (2020): 689-699.
Peraturan Pemerintah Republik Indonesia Nomor 50 Tahun 2021. :, 2021.

Pratama, Nanda Reza Putrazenny Rezania Dewantary. "State's Legal Protection To Copyright Holders Of Songs In Relation To The Online Songs Piracy" (2018). . "State's Legal Protection To Copyright Holders Of Songs In Relation To The Online Songs Piracy Nanda" (N.D.).

Rami Jened. "Konflik Yurisdiksi Dan Penegakan Hukum Kekayaan Intelektual Dalam Pasar Tunggal" Volume 28, No. Mimbar Hukum (2016): 201-214.

Shindell, Lawrence M. "Provenance And Title Risks In The Art Industry: Mitigating These Risks In Museum Management And Curatorship." Museum Management And Curatorship 31, No. 5 (2016): 406-417.

Suka Asih K.Tus, Desyanti. "Hak Ekonomi Dan Hak Moral Karya Cipta Potret Di Sosial Media." Vyavahara Duta 14, No. 1 (2019): 12.

Wiradirja, Imas Rosidawati. "Pelanggaran Hak Moral Atas Karya Cipta Dalam Penerbitan Elektronik." Jurnal Ilmu Hukum Litigasi 14, No. 1 (2013): 1662-1697.

Undang-Undang Republik Indonesia Nomor 28 Tahun 2014 Tentang Hak Cipta, 2014. 
HALAMAN KOSONG 